\title{
Slovarska delavnica v Leksikološki sekciji Inštituta za slovenski jezik Frana Ramovša ZRC SAZU v obdobju 1977-2002
}

\author{
Alenka Gložančev
}

IZVLEČEK: Na uvajalnem seminarju je bil predstavljen pomen Leksikološke sekcije ISJ FR ZRC SAZU, kot se kaže iz del, objavljenih v letih 1977-2002. Analitično je bilo osvetljeno konkretno slovaropisno delo, zlasti SSKJ, v perspektivi novih slovarskih projektov pa odprt jezikoslovno utemeljen razmislek o sodobnejšem, elektronsko podprtem nadgrajevanju klasičnega slovaropisnega pristopa.

A Lexicographic Workshop in the Lexicological Section of the Fran Ramovš Institute of the Slovene Language at SRC SASA 1977-2002 ABSTRACT: The importance of the Lexicological section of the Fran Ramovš institute of the Slovene language SRC SASA, evaluated on the basis of its publications between 1977 and 2002, has been discussed in an introductory seminar. An analysis of practical lexicographic work has been carried out, with special attention paid to the Dictionary of Standard Slovene. In the perspective of current lexicographic projects new linguistic challenges were considered in relation to contemporary computer-aided lexicography which should be used in addition to older lexicographic methods.

Seminar z naslovom Slovarska delavnica v Leksikološki sekciji ISJ FR ZRC $S A Z U$ (zlasti ob SSKJ) v obdobju 1977-2002 je bil zasnovan interno, namenjen pa je bil mladim raziskovalcem $v$ Leksikološki sekciji ter drugim mlajšim sodelavcem Inštituta. Potekal je po programu, ki sem ga kot izvajalka oblikovala na pobudo vodje Leksikološke sekcije, dr. Andreje Žele, in je bil predložen v presojo in soglasje predstojnici ISJ FR prof. dr. Varji Cvetko Orešnik. Organizacijsko je bil seminar razdeljen na tri delovne dneve (28. 10., 4. 11., 11. 11. 2003); potekal je vsakič od 9.00 do 13:30. V prvi polovici vsakega seminarskega dne so bile predstavljene teme po vnaprej določenem programu, udeležencei so prejeli orientacijska navodila za konkretno praktično delo, ki naj bi bilo opravljeno v drugi polovici istega seminarskega dne ali pa najkasneje na naslednjem seminarskem dnevu.

Namen seminarja je bil uvod v konkretno slovarsko delo s spodbudo h kritičnemu razmisleku zanj ob predstavitvi postopkov slovaropisnega dela ob SSKJ. Pri tem sta bila vodilna dva cilja: (1) seznanitev novih, mlajših sodelavcev s tradicijo in specifiko slovarske hiše, kjer se udejanjajo skupni slovarski projekti, (2) uzaveščenje 
potrebe po ekvivalentnih vzporednicah slovarskim postopkom pri SSKJ pri nadaljnjih slovarskih delih oz. po pretehtanem oblikovanju operacionalizacijskih načinov za določeno konceptualno slovarsko izhodišče, kar je posebej pomembno pri uvajanju sodobnejših, računalniško podprtih načinov slovaropisja.

V nadaljevanju poročila ob pregledu programa ${ }^{1}$ podajam nekaj informativnih povzetkov in poudarkov.

\section{Razčlenjeni pregled programa seminarja Slovarska delavnica $v$ Leksikološki sekciji Inštituta za slovenski jezik FR ZRC SAZU (zlasti ob SSKJ) v obdobju 1977-2002}

\section{Informativni del}

1 Mesto in pomen Leksikološke sekcije ISJ FR ZRC SAZU v zadnjih petindvajsetih letih, kot se kaže skozi objavljena dela ${ }^{2}$

1.1 Objavljena dela po projektih: Slovar slovenskega knjižnega jezika I, II, III, IV, V (1970, 1975, 1979, 1985, 1991), v eni knjigi (1994), na disketah (1997); Slovar slovenskega knjižnega jezika z Odzadnjim slovarjem slovenskega jezika in Besediščem slovenskega jezika z oblikoslovnimi podatki, elektronska izdaja na CD-romu (1998, 2000); Slovar slovenskega knjižnega jezika, Poskusni snopič (20 str.; 1964); Besedišče slovenskega jezika (2 knjigi: A-N, O-Ž) (1987), dodatni zvezek (1994, interna izdaja); Odzadnji slovar po Slovarju slovenskega knjižnega jezika (Hajnšek - Holz, Jakopin) (1996); Besedišče slovenskega jezika z oblikoslovnimi podatki (1998); Slovenski pravopis (2001).

1.1 Druga pomembnejša objavljena dela v obdobju 1977-2002, ki so v navezavi s slovarsko delavnico v Leksikološki sekciji

Avtorske monografije raziskovalcev - sodelavcev Leksikološke sekcije (8); temeljno slovensko slovaroslovno delo, nastalo po izidu SSKJ: Slovensko leksikalno pomenoslovje: Govorica slovarja (Ada Vidovič Muha, Ljubljana, 2000). - Konkretno praktično delo je bilo usmerjeno $\mathrm{v}$ analitični pristop $\mathrm{k}$ besedam oz. besednim zvezam na določenih straneh prej predstavljenih knjižnih del z vidika jezikoslovčeve kompetence in s ciljem slovaropisno-slovnične oz. jezikoslovnoraziskovalne perspektive.

\section{Delo za (in ob) SSKJ}

2.1 Dosedanji interni slovaropisni seminarji v Leksikološki sekciji

Za SSKJ: leta 1964, ob začetku dela za SSKJ: seminar za obdelovalce (redaktorske pomočnike) in seminar za redaktorje; leta 1980, ob začetku dela za četrto

1 Enote programa seminarja Slovarska delavnica v Leksikološki sekciji ISJ FR ZRC SAZU (zlasti ob SSKJ) v obdobju 1977-2002 so v tem poročilu navedene v krepkem tisku.

2 Pri soavtorskih delih so tu načeloma navedeni le naslovi in leto izida, ne pa tudi ostali bibliografski podatki. 
knjigo SSKJ: uvajalni seminar za nove sodelavce pri SSKJ. Namen internih seminarjev: uvajanje v kolektivno slovarsko delo, utrjevanje dogovorjenega in s tem ohranjanje možnosti za konsistentnost obsežnega in časovno dlje časa trajajočega projekta (kot je bil SSKJ), medgeneracijsko vzajemno strokovno dopolnjevanje.

\subsection{Tehnološki način dela}

Klasični rokopisni oz. tipkopisni način dela pri SSKJ in v glavnem tudi pri SP 2001; 1990 začetek uvajanja računalniške tehnologije na ISJ, zlasti v Leksikološki sekciji: začetni obseg in razmah; pomen Laboratorija za korpus slovenskega jezika (ustanovljen novembra 2001; temeljna raziskava: besedilni korpus Nova beseda).

\subsection{Gradivo za SSKJ}

\subsubsection{Listkovne kartoteke}

Predstavitev vseh šestih klasičnih listkovnih kartotek v Leksikološki sekciji; najpomembnejša Splošna kartoteka ( 6 milijonov listkov; gradivo, zbrano v obdobju 1948-1991) - najobsežnejša slovenska klasična listkovna kartoteka; pomen zlasti za SSKJ.

\subsubsection{Vprašanje elektronskih zbirk}

$\mathrm{V}$ času priprave SSKJ elektronskih zbirk še ni bilo.

\subsection{Klasična pot do gradiva za SSKJ}

$\mathrm{V}$ času oblikovanja korpusov kot temeljev za pripravo geslovnikov in sobesedilnih virov za različne slovarje je instruktiven pogled v zgodovino nastajanja gradivnih zbirk; udeleženci so bili seznanjeni z vrstami ekscerpiranja (popolni izpis, gosti izpis, paberkovalni izpis, posebni izpis, kombinirano ekscerpiranje), s standardiziranim načinom pisanja gesel in besedil, kot je bil uveljavljen že v začetku 60 -ih let dvajsetega stoletja pri Splošni kartoteki (1948-1991) ob pripravah za SSKJ; vrednost standardiziranega oblikovanja kartotečnih listkov s številnimi raziskovalno relevantnimi parametri; iz navedenega izhajajoča uporabnost pri konkretnem ciljnem projektu (SSKJ) in pri številnih drugih jezikoslovnih raziskavah bodisi sodelavcev Inštituta bodisi zunanjih uporabnikov tudi v kasnejšem času, s čimer se potrjuje nacionalni pomen te klasične listkovne kartoteke.

\subsubsection{Razporeditev listkovnega gradiva za eno besedo $v$ kartoteki}

Gre za osnovno gradivnoobdelovalno fazo, ki so jo kot pripravo za slovaropisno redakcijsko delo opravljali zunanji delavci - obdelovalci, sledeč dvema načeloma: osnovna, preprosta pomenska analiza (s sinonimnim ali približnim razlagalnim prikazom ter osnovna slovnično-skladenjska razpoznava: tako so za posamezno besedo $v$ kartotečnem gradivu nastali naslednji razdelki: seznam pomenov, sosledje pomensko grupiranega gradiva (in $\mathrm{v}$ okviru vsakega pomena razporeditev gradiva $\mathrm{z}$ vnaprej določenih skladenjskih vidikov), pomenske posebnosti, izrazito terminološko gradivo, izločeno (zaradi nestandardiziranosti kartotečnega listka, ki je onemogočala razvidnost raziskovalnih parametrov), vodilka (gradivo, ki navezuje geselsko besedo na druge sorodne ipd.). - Pomen tako standardizirane razporeditve listkovnega gradiva za slovaroslovno analizo in slovaropisni prikaz. - Iz tega je izhajala na seminarju poudarjena spodbuda udeležencem k opredelitvi sodobnejših, računalniško podprtih ekvivalentov klasičnim slovaroslovno-redakcijskim fazam (značilnim za delo pri SSKJ), ki bi bili v perspektivi vsaj v določeni meri aplikativni pri slovaropisju, temelječem na elektronskih besedilnih korpusih (katerih možnost uporabe je 
operativno bližja zlasti novi generaciji jezikoslovcev oz. raziskovalcev, zahteva pa seveda tudi nove, korpusom kompatibilne slovaropisne pristope).

\subsection{Izbor besedja za SSKJ}

Geslovnik za SSKJ nastajal v glavnem v 60-ih, 70-ih in prvi polovici 80-ih let dvajsetega stoletja, tj. $v$ "predračunalniškem obdobju«, torej na klasični način; pristop in operacionalizacija se kažeta $\mathrm{v}$ naslednjih internih delih: Seznam ekscerpiranih del (pripravljen leta 1965; približno 3155 enot), Splošni alfabetarij za pripravo slovarja sodobnega jezika (15 vezanih zvezkov formata A 4 po približno 1500 strani; za vsako knjigo SSKJ po trije), Dodatni splošni alfabetarij (5 vezanih zvezkov formata A 4; za vsako knjigo SSKJ po eden), Drugi dodatni splošni alfabetarij (5 vezanih zvezkov formata A 4; gradivo zbrano po letu 1985; alfabetarij pripravljen leta 1992), Splošni alfabetarij za dodatke (pripravljen leta 1985), Alfabetarij za vsako knjigo SSKJ (I-V) $(1964,1969,1973,1977,1981)$, Alfabetarij klasikov (vezani zvezek formata A $4 \mathrm{v}$ obsegu 489 strani, 1963), Začasni frekvenčni slovar (vezano, rokopisno; format A 4; 596 strani; priloga Frekvenčna rang lista (od frekvence 1000 (in) do 100 (zmerom); skupaj 611 strani; 1967).

2.6 Interni slovaropisni priročniki in pripomočki, nastali v času dela za SSKJ

Za možnost optimalno usklajenega kolektivnega slovarskega dela in za pomoč pri besedoslovnem raziskovanju je bilo sproti, v času priprave SSKJ, izdelano naslednje: Odzadnji slovar SSKJ (5 tipkopisnih zvezkov formata A 4, narejenih po alfabetariju za vsako knjigo SSKJ: I: 1966, II:1970, III: 1975, IV: 1977, V: 1982); Seznam kvalifikatorjev v SSKJ (narejeno za prve tri knjige SSKJ; s seznami s posameznim kvalifikatorjem označenih besed oz. pomenov; 3 vezani zvezki formata A 4, za interno uporabo, 1980); Seznam kvalifikatorskih pojasnil v SSKJ (s seznami s posameznim kvalifikatorskim pojasnilom opredeljene besede oz. pomena; 3 vezani zvezki, za interno uporabo, 1980); Koordinacijska kartoteka sinonimov (nastajala v redakcijski fazi oblikovanja posamezne knjige SSKJ; dragocen redakcijski slovaropisni pripomoček, saj so za vsako besedo, ki je v SSKJ navedena kot sinonim drugi besedi oz. zvezi, načeloma navedene vse povezave; 6 slovaropisno pomembnih funkcij te kartoteke); Koordinacijska kartoteka razlag oz. razlagalnih besed (kot pomoč za opredelitev osnovne razlagalne besede pri razlagah besed, nanašajočih se na isto ali sorodno pomensko polje). Razlagalna in zlasti sinonimna kartoteka sta bili tisti pomembni stvarni koordinacijski sredstvi, ki sta zaradi svoje idejne zasnove in organiziranosti vzbujali občudovanje tudi pri tujih jezikoslovcih - slovaropiscih, ki so bili v času nastajanja SSKJ gostje Inštituta.

Pomembna interna dela, kjer so predstavljena slovaropisna SSKJ-jevska načela, so naslednji priročniki: Priročnik za tehnično stran gesel (Marta Silvester, 1978); Interni slovaropisno-redakcijski priročniki, nastali ob SSKJ (1981; izdelano ob uvajalnem seminarju za nove sodelavce; 3 vezani zvezki formata A 4): Splošne informacije za redaktorje SSKJ (189 str.), Napotki za redakcijo samostalnika, pridevnika in glagola $v$ SSKJ - 1. del (211 str.), Napotki za redakcijo samostalnika, pridevnika in glagola $v$ SSKJ - 2. del: Tipske razlage (183 str.). 


\section{Slovaropisno-redakcijski del}

\section{Faze v postopku redakcijskega dela pri SSKJ}

Tri stopnje: osnovna gradivnoobdelovalna stopnja (opravljali zunanji sodelavci - obdelovalci), slovaroslovno redakcijska stopnja (temeljna: opravljali vsi raziskovalci - redaktorji samostojno; v primeru terminološko kvalificiranih besed ali pomenov pomemben posvet s terminologom), slovaroslovno pregledovalna in usklajevalna stopnja (opravljali načeloma po končanem redakcijskem delu za posamezno knjigo SSKJ, približno leto pred izidom knjige, izkušenejši raziskovalci - redaktorji).

Na seminarju je bila podana predstavitev nastajanja slovarskega sestavka (od kartotečnih listkov do redakcije) ob besedah list, ločiti, likvidacija. - Ob osnovnih načelih pomenske in socialno-funkcijske analize besed so bili poudarjeni postopki za dosego koherentnosti slovarja in pripomočki, izdelani ob SSKJ prav v ta namen: ob redakciji besede ptica je bilo predstavljeno, kako je lahko sinonimna kartoteka usmerjala pri redakciji, katere so bile njene obvezne in fakultativne smernice.

\section{Pogled na slovaropisne kategorije v SSKJ - vprašanje določenih kategorij v SSKJ (vprašanje perspektive za SNB)}

Izhodišče za ta redakcijsko najpomembnejši razdelek je bil članek z naslovom Predstavitev slovaropisnih kategorij za enojezični razlagalni slovar srednjega obsega - s temeljnim izhodiščem v SSKJ (L. Bokal, A. Gložančev, P. Kostanjevec, N. Vojnovič; Jezikoslovni zapiski 9/1, 2002). Ob tem je bilo obravnavano naslednje: pomen posameznih slovaropisnih kategorij in uvid v njihovo smiselnost, pomenoslovni prehodi preko metonimije in metafore ter $\mathrm{s}$ tem $\mathrm{v}$ zvezi vprašanje novega pomena ali le podpomena (znak //), vloge znaka za pomenski odtenek (/), povednost ilustrativnega gradiva (npr. pri besedi most), kvalifikatorsko pojasnilo $s$ prilastkom, kvalifikatorska pojasnila $v$ zvezi, $v$ zvezah, navadno $v$ zvezah, slovnična problematika ob kvalifkatorju neskl. pril., nekaj težjih mest za branje glav v slovarskem sestavku (nositi nošen; vse potencialne oblikoslovne možnosti za zapis glave za besedo fant in interpretacija teh možnosti): vprašanje smiselnosti naglasno-oblikoslovnih shem v Uvodu v SSKJ (morda drugačna opcija za bodoče slovarje?), raba sinonimov pri geslih oz. pomenih, označenih s kvalifikatorjem poljud., nestrok. (vprašanje stika s terminologijo oz. s procesom determinologizacije, značilne za sodobno jezikovno stanje), mesta, ki po osnovnem slovaropisnem načelu, sprejetem za SSKJ, zahtevajo nevtralni sinonim: utemeljitev in pomen tega načela.

3 Diskusijski del o slovaropisnih in redakcijskih problemih v SSKJ, zlasti s perspektivo konkretnega redakcijskega dela pri SNB

Intenziven diskusijski odziv udeležencev ob predstavljeni gradivni in slovaropisni problematiki je pokazal, da se je ob delu za SSKJ v Leksikološki sekciji izoblikovala pomembna slovarska delavnica, ki novim, mladim raziskovalcem ob njihovem siceršnjem teoretičnem poznavanje slovaroslovja (tudi zaradi ustreznega študijskega predmetnika na fakulteti, ki so ga deležni sedanji diplomanti slovenistike) in ob njihovi osebni zavzetosti za jezikoslovno delo lahko pomeni dragocen temelj 
- za sodelovanje pri novih slovarskih projektih, ki bodo - seveda času in tehnološkim možnostim primerno - verjetno temeljili na operacionalizacijsko sodobnejših, računalniško podprtih postopkih.

\section{Za sklep poročila}

Seminar je potekal $\mathrm{v}$ živahnem, tudi kritično premišljenem delovnem razpoloženju. - V treh seminarskih dneh so bile udeležencem podane temeljne informacije o slovarski delavnici v Leksikološki sekciji. Predstavljene so bile zlasti tri njene razsežnosti: gradivne zbirke, končni slovarski izdelki (ob SSKJ tudi slovaroslovni redakcijski proces), interni slovarski pripomočki in priročniki (popisani v enoti 2.6 tega poročila), nastali ob SSKJ, ki po svojem obsegu in vsebini kažejo na izjemno delovno raziskovalno energijo njihovih sestavljavcev, obenem pa so tudi za današnjega raziskovalca ob njegovem slovarskem delu lahko $\mathrm{z}$ več vidikov zgleden svetovalni in primerjalni vir.

\section{Literatura}

Milena Hajnšek - Holz, Delo za Slovar slovenskega knjižnega jezika, Jezikoslovni zapiski 4, Ljubljana, 1998, 9-18.

Ada Vidovič Muha, Slovensko leksikalno pomenoslovje: Govorica slovarja, Ljubljana, Znanstveni inštitut Filozofske fakultete, 2000.

Ostala literatura in viri, ki so bili predstavljeni udeležencem seminarja, so navedeni $\mathrm{v}$ vsebini poročila, dostopni pa so v knjižnici ali arhivu Inštituta za slovenski jezik Frana Ramovša ZRC SAZU. 